\title{
The Effect of English Access Microscholarship Program on Developing Speaking Skill From Graduate Students' Perspectives at the King Abdallah II for Excellence School in Zarqa-Jordan
}

\author{
Waleed Ayyad Al-Soufi \\ Master of Linguistics, Al al-Bayt Unversity, Jordan \\ E-mail: waleedalsoufiizz@yahoo.com
}

Received: June 21, 2021

Accepted: July 19, 2021

Published: August 22, 2021

doi:10.5296/ijl.v13i4.18774

URL: https://doi.org/10.5296/ijl.v13i4.18774

\begin{abstract}
The primary concern of this study is to investigate the effectiveness of English Access Microscholarship Program on developing the English Language Speaking Skill from the perspective of graduate students at the King Abdallah II for Excellence in Zarqa in the academic years from 2016 to 2020. The study also examined if Access Program encourages and motivates EFL learners to improve their speaking skills. In this study, the researcher designed a questionnaire consisting (40) items measuring students ' perspectives towards the effect of Access program in improving their speaking ability. The subjects of the research were 60 homogenous students aged 14 to 19. Students consisting three classes; FY14, FY15 and FY16 respectively. Each class had 20 students studying at King Abdallah II for Excellence School in the Directorate of Education in Zarqa, Jordan. The results revealed that the overall degree of the students' perspectives towards the effect of access program was high in improving their speaking skill and improved the participants`speaking skill. Moreover, the findings revealed that there were no statistically significant differences among students in their perspectives towards the effect of access program on developing their speaking skill. Finally, the researcher recommended that further studies should be conducted to measure the impact of access program in developing the four language skills (Listening, speaking, reading and writing).
\end{abstract}

Keywords: English Access Microscholarship Program, Speaking skill, Perspectives 


\section{Introduction}

\subsection{Background of the Study}

English is the most widely spoken language in the world due to its dominance and importance in a variety of sectors, including education, science, engineering, technology, trade, and tourism. English is a major subject in Jordan; students are required to study it as a compulsory subject in all educational curricula at schools and universities. As a result, learning English requires students to develop proficiency in four language skills: speaking, writing, reading, and listening. Among the four skills, speaking is considered a necessity for second language learners, and speaking can only be accomplished through interaction, performance, and transaction. (2008) (Richards). Additionally, speaking is crucial because it is required for communication on an international level. Students who typically speak English well have a better chance in life in terms of job offers, promotions, and even continuing their studies (Baker and Westrup, 2003).

According to U.S. Embassy in Amman (2015), the US Embassy in Amman has offered the Access program in Jordan since 2006, enrolling nearly 3,000 Jordanian students over the years. Students receive 400 hours of English language instruction and additional workshops designed to familiarize Jordanian students with American culture, community service, policy issues, and career development resources. With the addition of extracurricular activities, the English language curriculum strengthens students' English speaking, writing, listening, and reading skills. Guest speakers in the classroom, field trips to their country for cultural activities (such as films, exhibitions, and concerts), and visits to various organizations are all possible activities.

According to Amideast in Amman, the Access Program's overall goal is to improve disadvantaged youth's English language skills, resulting in increased self-confidence, strengthened critical thinking abilities, and opportunities to study or obtain jobs. One of the Access Program's fundamental goals is to develop students' communication and critical thinking skills through meaningful interaction, cooperative learning strategies, interest-based activities, and real-world contexts. Additionally, through a variety of experiential learning activities, Access seeks to prepare students for conversational English language skills with native and non-native speakers of American English. The Access program focuses primarily on the four language skills of reading, writing, speaking, and listening, as well as on communicative teaching methods that include time for both accuracy (grammar) and fluency (freely speaking). The purpose of learning English in the Access Program is to equip students with the ability to communicate in English in order to supplement their primary skills. Many people believe that the primary ability required to communicate in English is the ability to speak. The ability to communicate in English is defined as the capacity to comprehend and produce spoken or written language. It is comprised of four components: listening, speaking, reading, and writing.

\subsection{Statement of the Problem}

The purpose of this study is to assess the impact of the English Access Microscholarship 
Program on students' development of their English Language Speaking Skill. Thus, the purpose of this study was to determine the effectiveness of the English Access Microscholarship Program in resolving some of the difficulties that students face when speaking for various reasons such as lack of confidence, fear of making a mistake, shyness, and feeling anxious.

\subsection{Questions of the Study}

This study aims to answer the following questions:

1. What are the perspectives of EFL students at King Abdullah II School of Excellence in Zarqa-Jordan towards the effect English Access Microscholarship program in improvement their speaking skill?

2. Are there any statistical significant differences at $(\alpha \leq 0.05)$ among students' perspectives towards the effect of access program on developing their speaking skill?

\subsection{Hypothesis of the Study}

This study attempts to test the following hypothesis:

English Access Microscholarship Program has a positive effect on improving English speaking skill of Jordanian students who graduated from this program.

\subsection{Significance of the Study}

The primary objective of this research is to determine the extent to which the English Access Microscholarship Program has improved the students' speaking skills at King Abdullah II for excellence school between 2016 and 2020 academic years. Additionally, the study's significance stems from the fact that English access programs place a premium on developing students' speaking abilities.

\section{Literature Review}

\subsection{Program Description and History}

The English Access Microscholarship Program provides English language instruction to non-elite 14-18-year-old students in 44 countries with sizable Muslim populations via a US-style classroom experience. The first Access Program began in May 2003 in Casablanca, Morocco, with seventeen students. The Program was officially launched in January 2004 by the Bureau of Educational and Cultural Affairs (ECA). The Access Program has been funded by the ECA, the Middle East Partnership Initiative (MEPI), the Office of the Under Secretary for Public Diplomacy and Public Affairs (R), and regional Public Diplomacy (PD) bureaus since its inception. In October 2005, the Access Program was transferred from ECA's Office of English Language Programs to the Office of English Language Programs. Access programs are managed directly by Public Affairs Sections (PAS) at the local level, with assistance from the ECA and Regional English Language Officers (RELOs). (Office of Policy and Evaluation, US Department of State, Bureau of Educational and Cultural Affairs, 2007).

English Access Microscholarship Program (Access) is a United States Department of 
State-funded global scholarship program. It started in 2004 that has benefited approximately 110,000 students in more than 80 countries. A foundation of English language skills is provided to disadvantageous youth of 13-20 year-olds through after school classes and intensive sessions. In this program, students are exposed to U.S. culture and democratic values through enhancement activities. Also, selected students are equipped with strong four English language skills that can lead them to educational prospects, better jobs, and also gain the ability to compete for and participate in future exchanges and study in the United States (U.S. Department of State, 2015). According to U.S embassy in Amman, Access program has benefited almost 3,000 Jordanian students participating throughout the years (U.S Embassy in Amman, 2007)

The program's objectives are as follows: 1) to provide free English language classes to students from economically disadvantaged families; 2) to enable these students to develop leadership and interpersonal skills through various enhancement activities; 3) to increase students' understanding of American culture and ideals through enrichment activities; and 4) to provide students with improved English language skills. 5) to develop their critical thinking skills; 6) to increase their computer literacy; 7) to encourage them to participate in community service activities; 8) to help them obtain better jobs to support their families; 9) to help them access educational opportunities; and 10) to help them become better citizens. (Department of State of the United States, 2015).

\subsection{Speaking Skill}

Speaking is a productive skill. Obviously, learning to speak a language is more difficult than learning to understand it. Students must exert greater effort, and the teacher must show greater concern for the sequential arrangement of activities. 333-334 (Chastain). Communication is critical for expressing ideas and emotions. Speaking is one method of communication. Speaking is one of the four skills of the language (reading, writing, listening and speaking). Speaking is a productive skill that involves the production of systematic verbal utterances, which are simply words used to convey meaning. It is a collaborative process of meaning construction that entails the generation, receipt, and processing of information. (1999, p. 1) (Florez, 1999, p. Speaking serves two primary purposes. Speaking is either transactional in nature, conveying information and facilitating the exchange of goods or services, or interpersonal in nature, establishing and maintaining social relationships. p.13) (Thornbury). According to Bailey and Nunan (2005:2), "speaking is an interactive process of meaning construction that entails the production, receipt, and processing of information.". Speaking is critical because it is necessary for communicating on an international level. Students who typically speak English well have a better chance in life in terms of job offers, promotions, and even continuing their studies (Baker and Westrup, 2003). Mastery of the speaking skill is a prerequisite for second language learners and can be accomplished only through oral interaction, performance, and transaction. (2007) (Richards 2008)

\subsection{The Components of Speaking Skill}

According to Chastain (1976), speaking consists of three primary components: pronunciation, vocabulary, and grammar. They are necessary and critical for the successful development of 
any language's speaking ability.

\subsubsection{Pronunciation}

Pronunciation is a critical aspect of communication. As a result, if students struggle with a particular sound, the teacher should assist them by describing tongue and lip movement. Students who possess the ability to achieve a near-native accent should not be denied the opportunity; however, those who lack that ability should be allowed to learn to communicate in the language, as communication is more important than pronunciation. Additionally, he stated that the teacher's role in teaching pronunciation is to first identify the differences and then practice them in class by having students repeat phrases and sentences they have just heard (338; Chastain).

\subsubsection{Vocabulary}

Vocabulary knowledge is critical for language learning. Obviously, vocabulary is acquired through the use of receptive skills. However, vocabulary that is relevant to the learner's life experiences and can be used in meaningful communicative contexts is more likely to be internalized, useful, and retained. To maximize the number of words learned, the first step is to ask students to learn words that they can use to describe themselves. The second step is to increase the frequency with which these words are used in communicative situations. The third step is to attempt to reintroduce these words on a regular basis in order to prevent them from being

\subsubsection{Grammar}

Grammar is also a critical component of spoken language because it facilitates the acquisition of speaking ability, and if second language learners wish to improve their speaking ability, they must apply the rules of the target language's grammar. While native speakers intuitively understand these rules, second language learners must either consciously or unconsciously acquire them. In the case of grammar, the teacher should establish a required core of grammar for the students. Students who have difficulty meeting this minimal standard should be provided with specially prepared compensatory instructional materials that the teacher believes will assist them in overcoming their obstacles. Additionally, teachers are responsible for not only assisting students in acquiring the necessary communication skills; they are also responsible for creating situations that encourage students to express themselves.

\subsection{Basic Types of Speaking}

Brown (2004) asserts that there are several fundamental modes of speech, as defined by the following taxonomy:

1. Imitative. The ability to simply parrot back (imitate) a word, phrase, or possibly a sentence is at one end of a continuum of types of speaking performance. While this is a purely phonetic level of oral production, the criterion performance may incorporate a number of prosodic, lexical, and grammatical properties of language.

2. Intensive. A second type of speaking that is frequently used in assessment is the production 
of brief stretches of oral language that demonstrate competence in a narrow band of grammatical, phrasal, lexical, or phonological relationships.

3. Responsive. Responsive assessment tasks include interaction and comprehension testing, but on a more limited scale, such as very brief conversations, standard greetings and small talk, simple requests and comments, and the like.

4. Interactive. The distinction between responsive and interactive speaking is in the duration and complexity of the interaction, which may involve multiple exchanges and/or participants. Interaction can take two forms: transactional language, used to exchange specific information, or interpersonal language, used to maintain social relationships.

5. Extensive. Speeches, oral representations, and storytelling are all examples of extensive oral production tasks in which the opportunity for oral interaction from listeners is either severely limited (perhaps to non-verbal responses) or completely eliminated.

\subsection{Developing Speaking Skills}

Through a variety of experiential learning activities, Access aims to prepare students for conversational English language skills with native and non-native speakers of American English. Thus, developing students' speaking skills is critical to enabling students to communicate effectively in English, as it is one of the most effective methods of learning a language and developing speaking skills. According to Richard (2009, p.16), meaningful communication and interaction between learners facilitates learning. Bygate (1987, p.1) asserts that speaking is the most frequently judged skill and the one that determines whether they make or lose friends. It is the quintessential vehicle for social solidarity, social standing, professional advancement, and commerce. It is also a medium through which a great deal of language is learned, and one that is particularly conducive to learning for many. Perhaps then, the teaching of speaking merits additional consideration.

Speaking, on the other hand, is a skill that requires attention in both first and second languages. Despite the fact that students desire to improve their oral communication skills in a second language, they are frequently hesitant to participate in activities that will help them improve their oral communication ability. Overcoming these obstacles requires the teacher to pay close attention to the students' need for encouragement and support in developing their speaking abilities. Chastain (Chastain, 336) emphasizes the critical role of teachers in developing students' speaking abilities in English classrooms. Indeed, there are numerous strategies for developing speaking skills in the EFL classroom. For instance, enthusiasm for language study, particularly speaking, is strongly associated with success. Speaking cannot be developed in a classroom where students are fearful of responding in case they make a mistake. In successful classes, a competent teacher carefully nurtures the students' initial lack of confidence as they begin the semester. As a result, active class participation is critical for all language skills, but particularly for speaking. Additionally, the development of a friendly and warm classroom environment is a necessary precondition for a language class. Teachers should be receptive to and supportive of students' best efforts and work to dispel the myth that they are constant evaluators of each response. Sequencing is critical for the development 
of the speaking ability. Students engage in performance activities such as sub-performance drills, discussion of textual materials, using language to communicate in class, and relating material to the students (336; Chastain). Other effective strategies for developing oral skills in the EFL classroom focus on the various types of speaking activities that can be implemented, including discussions, speeches, role plays, conversations, audiotaped oral dialogue journals, and other accuracy-based activities MURCIA-CELCE (1979).

This study is noteworthy for its emphasis on speaking abilities, a subject on which numerous researchers have previously conducted research. For instance, Al-Shraideh, S. (2012) examined the English Access Microscholarship Program's effect on the development of Jordanian EFL students' communication skills, as well as teachers', students', and parents' perceptions of the program's effectiveness. He used three distinct types of participants to accomplish the study's objectives. 40 female EFL students from Sumaya Mixed School in the Al-Koura Directorate of Education; twenty students were assigned to the experimental group, while the remaining twenty students were assigned to the control group. Seven EFL teachers, male and female, who had been enrolled in the Access program. They were interviewed to ascertain their perceptions of the Access Program's efficacy in enhancing their students' communication skills and cultural awareness. Five parents of Access students were interviewed to ascertain their perceptions of the Access Program's efficacy in improving their daughters' communication skills and understanding of American culture. The study used a pre-post placement test to determine the effect of the Access program on students' English language communication skills. The conclusion indicated that students' perceptions of the Access program's effectiveness were favorable, EFL teachers' perceptions of the program's effectiveness were favorable, and Access students' parents' perceptions of the program's effectiveness were favorable.

S. Aoujil and D. Benattabou (2021) examined the role of the 'Access Program' in raising the achievement levels of Moroccan EFL students. The study is experimental in nature and is divided into two groups: experimental and control. The experimental group was treated by involving students in various 'Access Program' activities. The control group consisted of students on the same level as the experimental group, but without access to the 'Access Program' activities. After the program concluded, both groups were subjected to the same test. The findings indicated that students enrolled in the 'Access Program' outperformed students enrolled in the 'Non-Access' program in a variety of language skills. The paper concludes with a conclusion and some practical recommendations for practitioners in the field on how to incorporate these extracurricular activities into their practices.

Aguirre Division of JBS International, Inc (2007) assessed Access Program in six countries: Morocco, Lebanon, Oman, India, Bangladesh, and Pakistan. The evaluation's goals were to collect data from students, administrators, and instructors in order to better administer the program; to analyze the impact of the Access Program on students and their families; and to assess the impact of the Access Program on students and their families. assessing if the Access Programs in the aforementioned nations achieved their educational and cultural objectives; offering comments and recommendations for improving the standards of Access Program. The evaluation technique employed a formative evaluation component as well as a 
retrospective assessment of the Access Program in six nations. Data was collected using both quantitative and qualitative approaches, such as in-depth individual interviews, survey questionnaires, focus groups, discussion groups, and classroom observation. Public Affairs Sections employees, Regional English Language Officers, Access Program administrators/principals, selection committee members, instructors, students, peers of students, and parents of students were all used to obtain data. The review indicated that the majority of Access students' English abilities had improved, and that this improvement was attributable to the Access Program. Their English abilities were evaluated as good to outstanding.

In Russia, Mixon (2009) presented a multi-media initiative with Access students. The stories produced by Access students as a consequence of writing workshops at Access Program summer schools in five different Russian cities were featured in this project. The stories were developed as a way to improve language abilities in general and writing skills in particular, as well as to improve vocabulary. In conclusion, the stories were written as a complete language anthology book with the goal of strengthening communication skills while including cooperative and collaborative learning. According to the researcher, the Access program gave pupils the opportunity to experience an American-style classroom with American curriculum and supplies. The program also featured cultural studies, computer and internet studies, and hands-on student-centered activities that focused on the English immersion setting.

Berger (2009) looked at four different public diplomacy initiatives, one of which was the Access Program. In relation to the program, the researcher stated that it is likely that Access learners expected their English to improve considerably after participating in it. According to Berger, Access students may have felt pushed to demonstrate the program's success, and they may have overstated their progress in order to look intelligent and hardworking to the American assessors who reviewed the program. The researcher emphasized how the Access program was assessed, stating that the assessors gathered their data from several sources. Interviews, questionnaires, and focus groups were conducted. Participants, classmates, parents, instructors, and program administrators were assessed in the classes that were observed. The Access students saw themselves as having improved their English language abilities as a result of their participation in the program. Access students and their classmates who did not engage in the program were polled on their self-esteem and attitudes toward the United States. The Access students appeared to be more confident and have more favorable opinions of the United States. However, the researcher claimed that the discrepancies might be due to a variety of factors other just being Access participants. When asked if they were interested in joining in that program, all but one of the peers replied yes and expressed their desire to do so. According to the Access program's parents, their Access students communicated what they had learned with them and with their family members.

\section{Method}

This chapter describes the population, sample, and instrument of the study in addition to the validity and reliability of the instrument. Moreover, it explains the procedure and the statistical analysis utilized in this research. 


\subsection{Sample of the Study}

The sample of the study consisted of 60 EFL graduate students enrolled in English Access Microscholarship program at the King Abdullah II School of Excellence.in the academic years (2016-2020).

The table shows the distribution of students according to their classes.

Table 1 . The frequencies and percentages of the study sample for the class variable

\begin{tabular}{ccc}
\hline The class & Frequencies & Percent \\
\hline FY14 & 20 & 33.3 \\
FY15 & 20 & 33.3 \\
FY16 & 20 & 33.3 \\
\hline Total & 60 & 100
\end{tabular}

Table 1 shows the frequency and percentage of the study sample of the variable of the class, as it was found that the frequencies were equal among all grades, and the number of each repetition was (20) and the percent was (33.3\%).

\subsection{Research Instrument}

The researcher designed five-point Likert scale questionnaire to collect the data of the study. The questionnaire aimed at exploring EFL students' perspectives towards the effect of English Access Microscholarship program in speaking skill improvement The questionnaire has 40 scale items with five Likert-type responses ranging from 'strongly agree', 'agree', 'neutral', disagree', and 'strongly disagree'. The questionnaire was distributed to the students by publishing an electronic questionnaire.

\subsection{Instrument Validity and Stability}

In order to verify the indications of the authenticity of the study tool in its initial form, it was presented to a group of experienced and competent referees, with the aim of judging the degree of soundness of the linguistic wording of the paragraphs and their clarity, and the extent of their suitability to measure what they were designed for, and the extent to which each paragraph belongs to the scale and the field to which it belongs, In addition to any action required to delete, amend or add to the paragraphs of the questionnaire, or suggestions they deem appropriate, the arbitrators' comments and proposals were taken into account and the questionnaire was amended based on the consensus of the majority of the arbitrators, and the questionnaire was released in its final form. Also, the researcher verified the construct validity of the questionnaire by using the Pearson correlation coefficient. The results are show in the below table. 
Table 2. The correlation coefficients

English Access Program has helped me to talk about myself appropriately

Pearson Correlation

Sig

English Access Program has helped me to present a great flexibility in communicating with people

0.77

$0.00 * *$

English Access Program has encouraged me to speak with confidence without any fear or shyness

0.84

$0.00 * *$

English Access Program has encouraged me to speak without hesitation or repetition

$0.00 * *$

0.73

$0.00 * *$

English Access Program has helped me to pronounce short and long vowels correctly

0.78

$0.00 * *$

English Access Program has helped me to pronounce with correct stress and intonation of words

0.82

$0.00 * *$

English Access Program has helped me to use appropriate body language according to the situation

0.77

$0.00 * *$

English Access Program has helped me to pronounce words with silent letters correctly

0.87

$0.00^{* * *}$

English Access Program has helped me to use self-correction when feeling wrong

0.88

$0.00 * *$

I can describe things in suitable ideas

0.71

$0.00 * *$

English Access Program has helped me to use synonyms and antonyms to clarify meaning

0.83

$0.00 * *$

English Access Program has helped me to use gratitude, greeting and apology phrases in their correct positions

0.75

$0.00 * *$

English Access Program has helped me to use verbal pause fillers like: 'it's like' 'hum', 'well'uh, mm, uha.

0.82

$0.00 * *$

English Access Program has helped me to use contractions like `what's` who`s

0.74

$0.00^{* *}$

English Access Program has helped me to pronounce the blended letters pairs (bl, br, gl, gr) correctly

0.84

$0.00 * *$

English Access Program has helped me to use suitable conjunctions to tie sentences together

0.77

$0.00 * *$

English Access Program has helped me to use suitable questions words in my speaking like: who, what, where, why and when

0.74

$0.00 * *$

English Access Program has helped me to use grammar structure and word order naturally

English Access Program has helped me to take part in a basic factual conversation on a predictable topic.

English Access Program has helped me to express simple opinions or requirements in a familiar context 
English Access Program has helped me to give a talk on a familiar topic or keep up a conversation

0.83

$0.00 * *$

English Access Program has helped me to deal confidently with open questions

$0.00 * *$

English Access Program has helped me to feel confident when speaking or interacting with people

0.88

$0.00 * *$

English Access Program has helped me to use exploratory phrases like: 'I think', 'because', 'why'.

0.89

$0.00 * *$

English Access Program has helped me to enjoy speaking English

$0.00 * *$

English Access Program has helped me to ask and answer authentic questions

0.88

$0.00 * *$

English Access Program has helped me to talk about any written text in my own words

$0.00 * *$

English Access Program has helped me to recognize reduced forms like: gonna (going to), wanna (want to), hafta (have to) easily

Access program has encouraged me to speak more English Access program has developed my presentation skills

Access program has helped me to understand the functions of language better

Access program has helped me to take notes from an audio such as conversations.

Access program has helped me to participate in an unplanned conversation in English about everyday topic

Access program has helped me to use a variety of vocabulary when participating in a conversation

0.85

$0.00 * *$

0.86

$0.00 * *$

$0.86 \quad 0.00 * *$

$0.87 \quad 0.00 * *$

$0.80 \quad 0.00 * *$

Access program has helped me to sit for a scholarship interview held in English

0.85

$0.00 * *$

0.80

$0.00 * *$

Access program has helped me to sit for a job interview held in English

$0.81 \quad 0.00 * *$

$0.75 \quad 0.00 * *$

Access program has helped me to express my opinion in a debate

$0.82 \quad 0.00 * *$

Access program has helped me to feel comfortable interacting with people from different cultures and beliefs

$0.87 \quad 0.00 * *$

Access program has helped me to practice English outside schools

$0.89 \quad 0.00 * *$

Access program has encouraged me to participate more in

English classes in school or university

$0.93 \quad 0.00 * *$

Table 2 shows that the correlation coefficients between each paragraph and total degree, ranged between (0.93-0.69), all of them significant at level (0.01), which are accepted to apply the study. 


\section{Macrothink}

International Journal of Linguistics

ISSN 1948-5425

2021, Vol. 13, No. 4

The stability of the study tool was extracted by applying the tool stability equation (Cronbach Alpha) to all measures and fields of the study tool. Table 3 illustrates this.

Table 3. The Cronbach Alpha test for the stability of the variables

\begin{tabular}{cc}
\hline Cronbach's Alpha & N of Items \\
\hline 0.989 & 40 \\
\hline
\end{tabular}

Table 3 shows the results of extracting Cronbach's Alpha coefficients to reveal the stability coefficients for the fields of the study tool, as it was (0.989) for the fields.

\subsection{Scale Correction}

The questionnaire has 40 scale items with five Likert-type responses ranging from 'strongly agree', 'agree', 'neutral', disagree', and 'strongly disagree'. The questionnaire was distributed to the students by publishing an electronic questionnaire. The following categories are used to judge the items estimations:

- Less than 2.33 low.

- from 2.34-3.66 medium.

- From 3.67 to 5.00 high.

\subsection{Statistical Analysis}

The following statistical treatment through statistical software packages (SPSS) were used:

- Frequencies and percentages of personal variables for the study sample.

- Correlation coefficients were calculated between each paragraph and the domain to which it belongs.

- Cronbach's internal consistency coefficient alpha for all fields of study.

- The arithmetic means and standard deviations of the answers of the study sample individuals for all areas of the study and their measures.

\subsection{Procedure}

1. The researcher developed and prepared the instrument of the study and verifying its' validity.

2. It was presented to a group of experienced referees and was arbitrated by a panel of raters (See Appendixes 1).

3. The questionnaire was edited according to the raters' suggestions (See Appendixes 2).

4. Participants' answers were analyzed to the questionnaire.

4. The SPSS program calculated Cronbach's alpha to ensure the reliability of the instrument.

5. The results were collected and analyzed statistically employing SPSS program. 


\section{Results and Discussions}

This chapter includes the results of the study that aimed to investigate the effect of the English access microscholarship program on improving speaking skill from the viewpoint of graduate students from the King Abdullah II School of Excellence in Zarqa 2016-2020 by answering the study questions.

1. What are the perspectives of students at King Abdullah II School of Excellence in Zarqa-Jordan towards the effect English Access Microscholarship program in improvement their speaking skill?

Table 4. Means, standard deviation, agreement degree and rank for the effect of English Access Microscholarship Program on developing the English language speaking skills from the perspective of graduates of King Abdullah II School of Excellence in Zarqa_Jordan 2016-2020"(N=60)

\begin{tabular}{|c|c|c|c|c|c|}
\hline \multicolumn{2}{|c|}{ No Items } & \multirow{2}{*}{$\begin{array}{l}\text { Mean } \\
4.37\end{array}$} & \multirow{2}{*}{$\begin{array}{c}\begin{array}{c}\text { Std. } \\
\text { Deviation }\end{array} \\
0.84\end{array}$} & \multirow{2}{*}{$\begin{array}{l}\text { Agreement } \\
\text { Degree } \\
\text { High }\end{array}$} & \multirow{2}{*}{$\frac{\text { Rank }}{1}$} \\
\hline 1 & $\begin{array}{l}\text { English Access Program has helped me to talk about } \\
\text { myself appropriately }\end{array}$ & & & & \\
\hline 2 & $\begin{array}{l}\text { English Access Program has helped me to present a } \\
\text { great flexibility in communicating with people }\end{array}$ & 3.98 & 1.10 & High & 33 \\
\hline 3 & $\begin{array}{l}\text { English Access Program has encouraged me to speak } \\
\text { with confidence without any fear or shyness }\end{array}$ & 4.2 & 0.87 & High & 10 \\
\hline 4 & $\begin{array}{l}\text { English Access Program has encouraged me to speak } \\
\text { without hesitation or repetition }\end{array}$ & 4.13 & 0.93 & High & 17 \\
\hline 5 & $\begin{array}{l}\text { English Access Program has helped me to pronounce } \\
\text { short and long vowels correctly }\end{array}$ & 4.20 & 0.97 & High & 11 \\
\hline 6 & $\begin{array}{l}\text { English Access Program has helped me to pronounce } \\
\text { with correct stress and intonation of words }\end{array}$ & 4.08 & 0.93 & High & 20 \\
\hline 7 & $\begin{array}{l}\text { English Access Program has helped me to use } \\
\text { appropriate body language according to the situation }\end{array}$ & 3.80 & 1.18 & High & 40 \\
\hline 8 & $\begin{array}{l}\text { English Access Program has helped me to pronounce } \\
\text { words with silent letters correctly }\end{array}$ & 4.22 & 0.96 & High & 9 \\
\hline 9 & $\begin{array}{l}\text { English Access Program has helped me to use } \\
\text { self-correction when feeling wrong }\end{array}$ & 4.07 & 1.01 & High & 22 \\
\hline 10 & I can describe things in suitable ideas & 4.18 & 0.91 & High & 12 \\
\hline 11 & $\begin{array}{l}\text { English Access Program has helped me to use } \\
\text { synonyms and antonyms to clarify meaning }\end{array}$ & 3.98 & 1.10 & High & 34 \\
\hline 12 & $\begin{array}{l}\text { English Access Program has helped me to use } \\
\text { gratitude, greeting and apology phrases in their } \\
\text { correct positions }\end{array}$ & 4.28 & 0.94 & High & 3 \\
\hline 13 & $\begin{array}{l}\text { English Access Program has helped me to use verbal } \\
\text { pause fillers like: 'it's like' 'hum', 'well'uh, mm, } \\
\text { uha. }\end{array}$ & 4.00 & 0.99 & High & 30 \\
\hline
\end{tabular}


14 contractions like `what's` who`s

15

English Access Program has helped me to pronounce the blended letters pairs (bl, br, gl, gr) correctly

16 English Access Program has helped me to use suitable conjunctions to tie sentences together

English Access Program has helped me to use

17 suitable questions words in my speaking like: who, 4.28 what, where, why and when

18

English Access Program has helped me to use grammar structure and word order naturally

19 English Access Program has helped me to take part in a basic factual conversation on a predictable topic.

20 English Access Program has helped me to express simple opinions or requirements in a familiar context

21 English Access Program has helped me to give a talk on a familiar topic or keep up a conversation

15

4.02

1.05

0.89

0.99

4.05

0.81

4.03

1.01

4.00

1.06

1.00

1.00

confidently with open questions

4.05

4.07

English Access Program has helped me to feel confident when speaking or interacting with people

24 English Access Program has helped me to use exploratory phrases like: 'I think', 'because', 'why'.

25 English Access Program has helped me to enjoy speaking English

4.18

4.23

0.96

0.96 any written text in my own words

English Access Program has helped me to recognize

28 reduced forms like: gonna (going to), wanna (want to), hafta (have to) easily

Access program has encouraged me to speak more English

Access program has developed my presentation skills

Access program has helped me to understand the functions of language better

32 Access program has helped me to take notes from an audio such as conversations.

Access program has helped me to participate in an

33 unplanned conversation in English about everyday topic
1.00

1.09

4.00

4.23

0.99

High

8

4.33

0.90

High

2

$4.10 \quad 1.09$

High

19

3.98

1.07

High

35

3.93

1.09

High

3.98

1.03

High

36 
Access program has helped me to use a variety of vocabulary when participating in a conversation

4.02

0.95

High

Access program has helped me to sit for a scholarship interview held in English

Access program has helped me to sit for a job interview held in English

Access program has helped me to express my opinion in a debate

Access program has helped me to feel comfortable

38 interacting with people from different cultures and beliefs

Access program has helped me to practice English outside schools

\begin{tabular}{llll}
4.12 & 0.94 & High & 18 \\
4.18 & 1.00 & High & 14 \\
4.25 & 0.97 & High & 5 \\
4.10 & 0.81 & High & \\
\hline
\end{tabular}

Access program has encouraged me to participate more in English classes in school or university

Total degree

Table 4 shows that the means ranged between (3.80-4.37). The highest means was (4.37) for item (1) " English Access Program has helped me to talk about myself appropriately" by high agreement degree, then for item (29) "Access program has encouraged me to speak more English" and item (12) "English Access Program has helped me to use gratitude, greeting and apology phrases in their correct positions"(means4.28) by high agreement degree and the lowest means was (3.80) for item (7) "English Access Program has helped me to use appropriate body language according to the situation". The total means for the effect of the English access microscholarship program on developing the English speaking skills from the perspective of graduates of King Abdullah II School of Excellence in Zarqa-Jordan 2016-2020 reached (4.10) by high agreement degree.

2. Are there any statistical significant differences at $(\alpha \leq 0.05)$ among FY14, FY15 and FY16 students' perspectives towards the effect of access program on developing their speaking skill?

There is no statistically significant impact at $(\alpha \leq 0.05)$ among FY14, FY5, and FY16 students perspectives towards the effect of English Access Microscholarship Program on improving English speaking skills from the viewpoint of graduate students from King Abdullah II School of Excellence in Zarqa 2016-2020. To test this hypothesis, means and standard deviation for the effect of the English ACCESS Micro scholarship program on developing the English language speaking skills due to (academic classes). 
Table 5. Means and standard deviation for the effect of the English ACCESS Micro scholarship program on developing the English language speaking skills due to (academic classes)

\begin{tabular}{lllll}
\hline \multirow{2}{*}{ Variable } & Category & $\mathrm{N}$ & Mean & $\begin{array}{l}\text { Standard. } \\
\text { Deviation }\end{array}$ \\
\hline \multirow{2}{*}{ FY14 } & 20 & 3.74 & 0.76 \\
\cline { 2 - 5 } & FY15 & 20 & 4.48 & 0.50 \\
\cline { 2 - 5 } Total degree & FY16 & 20 & 4.07 & 0.96 \\
\hline
\end{tabular}

The findings as shown on Table 5 present the number of students was (60). The means of achievement of the three classes were approximately equal in each item. The total means of all the items for the FY14 students was (3.74), FY15 students was (4.48) and FY16 students was (4.07). Therefore, it can be concluded that there are NO statistically significance differences in EFL students' perspective towards the effect of access program on developing their speaking skill due to gender (Academic Classes) variable.

\section{Discussion of Results}

1. What are the perspectives of EFL students at King Abdullah II School of Excellence in Zarqa-Jordan towards the effect English Access Microscholarship program in improvement their speaking skill?

Based on the results of this study, the total means for the effect of the English Access Microscholarship Program on developing the English speaking skills from the perspective of graduates of King Abdullah II School of Excellence in Zarqa-Jordan 2016-2020 reached (4.10) by high agreement degree. This result highlights the importance and the effectiveness of English Access Microscholarship Program as an effective program in improving the speaking skill of students. In fact, English Access Microscholarship Program plays a crucial role in improving students` ability to speak English better and is considered as one of the most useful and fundamental programs in enhancing students`speaking skill as it enables them to get fluency through communicating with others. It was found that the program can foster confidence in students to speak English appropriately. The participants' responses to most of the items in the questionnaire showed their high positive agreement of the effect of English Access Microscholarship program in improving their English speaking skill. The results of this question agree with the results of a study by S. Aoujil and D. Benattabou (2021) who investigated the role of the 'Access Program' in raising the achievement levels of Moroccan EFL students. The findings indicated that students enrolled in the 'Access Program' outperformed students enrolled in the 'Non-Access' program in a variety of language skills. The results of the current study are in line with the previous research which assured the 
positive impact of English Access Microscholarship Program on developing students' speaking skills (Berger, 2009; Mixon, 2009; Aguirre Division of JBS International Inc., 2007).

2. Are there any statistical significant differences at $(\alpha \leq 0.05)$ among FY14, FY15 and FY16 students' perspectives towards the effect of access program on developing their speaking skill?

In the light of the previously presented statistical analysis, it can be concluded that English Access Microscholarship Program had a notable effect on developing students` speaking skills observed through means of all the items. the total. The total means of all the items for FY14 students was (3.74), FY15 students was (4.48) and FY16 students was (4.07). The results revealed that there were no statistically significance differences among FY14, FY15 and FY16 students' perspectives towards the effect of access program on developing their speaking skill due to (Academic Classes) variable, since the means of achievement of the three classes were approximately equal in each item.

\section{Conclusion and Recommendations}

This study aimed to investigate the effectiveness of English Access Microscholarship Program on developing the English Language Speaking Skill from the Perspective of Graduated Students at the King Abdallah II for Excellence in Zarqa in the academic years from 2016 to 2020. The results revealed that the overall degree of the students' perspectives towards the effect of access program was high in improving their speaking skill and improved the participants`speaking skill. This result highlights the significance of English Access Microscholarship as an effective program in improving the speaking skill of students. The findings of the study also revealed that there were no statistically significant among students perspectives towards the effect of access program on developing their speaking skill. Moreover, the findings showed that English Access Microscholarship Program has a positive effect in different countries by comparing the results of this current study with the results of other studies that conducted around this program in other countries. Finally, the researcher recommended that further studies should be conducted to examine the impact of English Access Microscholarship Program on developing the other three language skills (Listening, reading and writing) for Access students. Further studies should be conducted to investigate the effect of English Access Microscholarship Program on other Jordanian directorates and other countries.

\section{References}

Access English Students Graduation. (2007). U.S. Embassy in Amman. Retrieved from https://jo.usembassy.gov/access-english-students-graduation/

Aguirre Division of JBS International Inc. (2007). Evaluation of the English Access Microscholarship Program: Executive Summary. U.S. Department of State: Public Diplomacy Evaluation Office. Washington, DC. Retrieved October, 2010, from http://storage.canalblog.com/47/01/680339/47087509.pdf

Al-Shraideh, S. (2012). The effect of the English Access Microscholarship Program on 
developing Jordanian EFL students' communication skills and teachers, students and their parents' perceptions of its effectiveness. Master`s Thesis: Yarmouk University.

Aoujil, S., \& Benattabou, D. (2021). The Impact of Extracurricular Activities on Language Learning: 'Access Program' in Morocco as a Case Study. International Journal of Linguistics, Literature Translation (IJLLT), 2617-0299. Retrieved from https://www.researchgate.net/publication/349663625

Bailey, K. M., \& Nunan, D. (2005). Practical English language teaching speaking. New York: Mec Graw-Hill Education.

Baker, J., \& Westrup, H. (2003). Essential Speaking Skills: A Handbook for English Language Teachers. London: Continuum.

Berger, E. (2009). Selling America: U.S. Public Diplomacy Programs in the Middle East and South Asia in a Post 9/11 Environment: Public Policy Honors Thesis. Sanford School of Public Policy, Duke University. Retrieved December 4, 2011, from http://ebookbrowse.com/elana- berger-thesis-final-pdf

Bureau of educational and cultural affairs: Exchange programs. (2018). Retrieved from https://exchanges.state.gov/non-us/program/english-accessmicroscholarship-program

Bygate, M. (1987). Speaking. New York: Oxford University Press.

Celce-Murcia. (1979). Teaching English as a Second or Foreign Language. In Lazaraton, A. (Ed.), Teaching Oral Skills (pp. 103-115). Heinle. Thomson Learning.

Chastain, K. (1979). Developing Second Language Skills: theory to practice (2nd ed.). University of Virginia.

Chastain, K. (1998). Developing Second Language Skills. (2nd ed.). Chicago: Harcourt Brace Publishers.

Florez, M. A. C. (1999). Improving Adult English Language Learners' Speaking Skills. ERIC Digest ED435204. Retrieved July 7, 2002 from ERIC database.

Kavaliauskienè, G. (2013). Ongoing research in to speaking skill. English for Specific Purposes World, 38(14), 1-9.

Mixon, M., \& English Access Microscholarship Students in Russia. (2009). Lessons in Kindness: Accessing English through Students Stories. 2nd Edition: Repetitor Multimedia. Retrieved 2010, from http://access.lingvograd.ru/book/ACCESS.pdf

Retrieved from https://en.wikipedia.org/wiki/Effectiveness

Retrieved from https://en.wikipedia.org/wiki/Skill

Retrieved

from https://www.amideast.org/jordan/find-a-scholarship/high-school-and-younger/english-accessmicroscholarship-access-program 
Richard. (2008). Teaching Listening and Speaking: From Theory to Practice. Cambridge: Cambridge University Press.

Thornbury, S. (2005). How to Teach Speaking. England: Pearson Educational Limited.

U.S. Department of State. (2007). Evaluation of the English Access Microscholarship Program Executive Summary. U.S. Department of State, Bureau of Education and Culture Affairs, Office of Policy and Evaluation. Aguirre Division of JBS International, Inc. 5515 Security Lane, Suite 800 Rockville, MD 20852.

U.S. Department of State. (2015). English access microscholarship program 2015-2016 program handbook for providers. U.S. Department of State, Bureau of Education and Culture Affairs, Office of English Language Programs.

\section{Appendix A. Jury Members}

These experts are well known professors who work at universities in Jordan

This table shows their names and academic positions

\begin{tabular}{cccc}
\hline No. & Name & Position & University \\
\hline 1. & Fawwaz Al-Abed Al-Haq & $\begin{array}{c}\text { Professor of English and } \\
\text { Linguistics }\end{array}$ & Hashemite University \\
\hline 2. & Ahmad ElSharif & $\begin{array}{c}\text { Associate professor of } \\
\text { Linguistics }\end{array}$ & Al-alBayt University \\
\hline 3. & Yazid Al-Sorty & Professor of Foundation of & Hashemite University \\
\hline 4. & Ali Farhan AbuSeileek & $\begin{array}{c}\text { Professor English Language } \\
\text { Methods and Curricula }\end{array}$ & Al-alBayt University \\
\hline
\end{tabular}

\section{Appendix B}

\begin{tabular}{|c|c|c|c|c|}
\hline Items: Speaking Skill & $\begin{array}{l}\text { Strongly } \\
\text { agree }\end{array}$ & Agree & Neutral & Disagree \\
\hline
\end{tabular}

1. English Access Program has helped me to talk about myself 
appropriately

2. English Access Program has enabled me to present a great flexibility in communicating with people

3. English Access Program has encouraged me to speak confidently without any fear or shyness

4. English Access Program has encouraged me to speak without hesitation .

5. English Access Program has aided me in correctly pronouncing short and long vowels

6. English Access Program has aided me in correctly stressing and intoning words

7. English Access Program has helped me to use appropriate body language in various situations

8. English Access Program has aided me in correctly pronouncing words with silent letters

9. English Access Program has helped me to use self-correction when feeling wrong

10. English Access Program has enabled me to describe things in suitable ideas

11. English Access Program has helped me to use synonyms and antonyms to clarify meaning

12. English Access Program has helped me to properly position 
phrases of gratitude, greeting, and apology

13. English Access Program has helped me to use to use verbal pause fillers such as: 'it's like' ‘hum', 'well'uh, mm, uha.

14. English Access Program has helped me to use contractions like ‘what's`who`s

15. English Access Program has helped me to pronounce the blended letters pairs (bl, br, gl, gr) correctly

16. English Access Program has helped me to use appropriate conjunctions to connect sentences.

17. English Access Program has helped me how to incorporate appropriate question words into my speaking, such as who, what, where, why, and when.

18. English Access Program has assisted me in developing a natural ability to use grammar structure and word order.

19. English Access Program has helped me how to participate in a simple factual conversation about a predictable subject.

20. English Access Program aided me in expressing straightforward opinions and requirements in a familiar setting.

21. English Access Program aided me in delivering a speech on a familiar subject or keep up a 
conversation.

22. English Access Program has helped me how to approach open questions with confidence.

23. English Access Program has given me confidence in my ability to interact with others

24. English Access Program has how to use exploratory phrases such as "I believe," "because," and "why.".

25. English Access Program has helped me to enjoy speaking English

26. English Access Program has assisted me in posing and responding to authentic questions

27. English Access Program has helped me to talk about any written text in my own words

28. English Access Program has made it easier for me me to recognize reduced forms like: gonna (going to), wanna (want to), hafta (have to) easily

29. Access program has motivated me to improve my English proficiency

30. Access program has honed my presentation skills and abilities.

31. Access program aided me in better comprehending the functions of language

32. Access program has aided me in taking notes during audio recordings such as conversations. 
33. Access program has enabled me to participate in an unplanned English conversation about an everyday topic.

34. Access program has helped me to use a variety of vocabulary when participating in a conversation

35. Access program has prepared me to sit for an English-language scholarship interview.

36. Access program has aided me in preparing for an English-language job interview.

37. Access program has aided me in expressing my viewpoint during a debate.

38. Access program has aided me in developing a sense of comfort when interacting with people of diverse cultures and beliefs.

39. Access program has provided me with opportunities to practice English outside of school

40. Access program has encouraged me to participate more in English classes in school or university

\section{Copyrights}

Copyright for this article is retained by the author(s), with first publication rights granted to the journal.

This is an open-access article distributed under the terms and conditions of the Creative Commons Attribution license (http://creativecommons.org/licenses/by/4.0/) 